\title{
5-Aminouracil as a Building Block in Heterocyclic Synthesis: Part III. One-pot Synthesis of Novel Pyrimido[5,4-b]quinoline-2,4,9-triones and Pyrimido[5,4-c]isoquinolines
}

\author{
Raafat M. Shaker ${ }^{\mathrm{a}}$, Kamal U. Sadek ${ }^{\mathrm{a}}$, Ebtisam A. Hafez ${ }^{\mathrm{b}}$, and Mohamed Abd Elrady \\ ${ }^{\text {a }}$ Chemistry Department, Faculty of Science, Minia University, 61519 El-Minia, Egypt \\ b Chemistry Department, Faculty of Science, Cairo University, Giza-12613, Egypt
}

Reprint requests to Prof. Dr. Raafat M. Shaker. E-mail: rmshaker@yahoo.com

Z. Naturforsch. 2010, 65b, 1485 - 1490; received June 27, 2010

\begin{abstract}
An efficient and direct procedure for the synthesis of pyrimido[5,4- $b]$ quinoline-2,4,9-trione and pyrimido[5,4-c]isoquinoline derivatives has been described. The products were characterized by elemental analyses, IR, ${ }^{1} \mathrm{H}$ NMR, ${ }^{13} \mathrm{C}$ NMR and MS spectra.
\end{abstract}

Key words: 5-Aminouracil, Dimedone, One-pot Synthesis, Pyrimido[5,4-b]quinoline-2,4,9-trione, Pyrimido[5,4-c]isoquinoline

\section{Introduction}

Polyfunctionalized heterocyclic compounds play important roles in the drug discovery process, and analysis of drugs in late development or on the market shows that $68 \%$ of them are heterocycles [1]. Therefore, it is not surprising that research on the synthesis of polyfunctionalized heterocyclic compounds has received significant attention. Pyrimidoquinolines have been an object of great interest to organic, medicinal and materials scientists over many years, as they are present in a number of biologically active organic compounds which exhibit antimalarial [2,3], anticancer [4], antitumor [5] antimicrobial [6], antiviral [7], analgesic [8], anti-oxidant [8], and anti-inflammatory activities $[8,9]$. Furthermore, multi-component reactions (MCRs) play an increasingly important role in organic and medicinal chemistry for their convergence, productivity, ease of execution, excellent yield, and broad application in combinational chemistry [10-18].

Recently, we reported a simple and efficient synthesis of pyrimido[5,4-b]quinoline-2,4,9-triones (4) [17], and pyrido[3,2- $d: 6,5-d \backslash$ dipyrimidines (6) [18] via the reaction of 5-aminouracil (1), benzaldehyde derivatives $\mathbf{2}$ and dimedone (3) or barbituric acid derivatives 5 under microwave irradiation without catalyst. These compounds could have interesting effects on biological targets (Scheme 1).

Considering the above reports and in continuation of our work in the development of new and simple

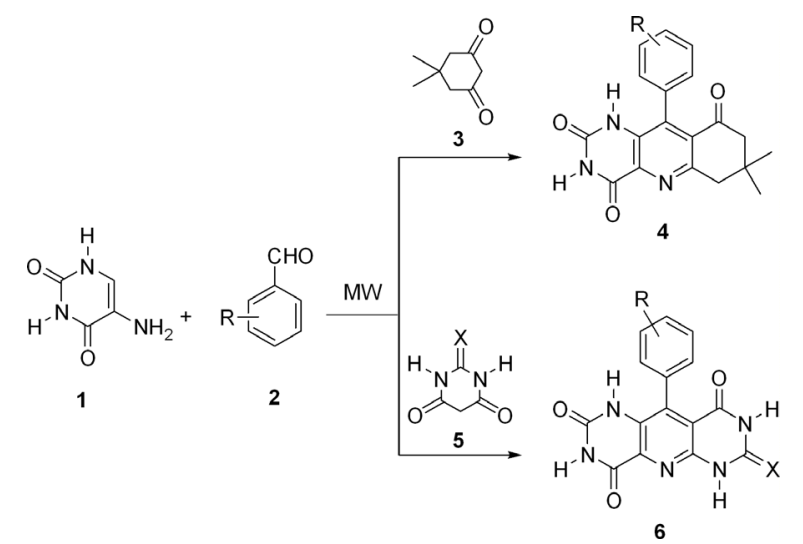

Scheme 1. Synthesis of pyrimido[5,4- $b]$ quinolines 4 and pyrido[3,2- $d: 6,5-d \backslash$ dipyrimidines 6 .

methods for the synthesis of polyfunctionally substituted heterocyclic compounds [17-28], we wish to report a novel and efficient one-pot method for the synthesis of pyrimido[5,4- $b$ ]quinoline-2,4,9-trione and pyrimido[5,4-c]isoquinoline derivatives with the purpose of investigating in the future their possible biological activity. The mechanism of the reaction has been proved via the synthesis of a proposed intermediate.

\section{Results and Discussion}

The reaction of 5-aminouracil (1), dimedone (3) and paraformaldehyde (7) in DMF and in the pres- 


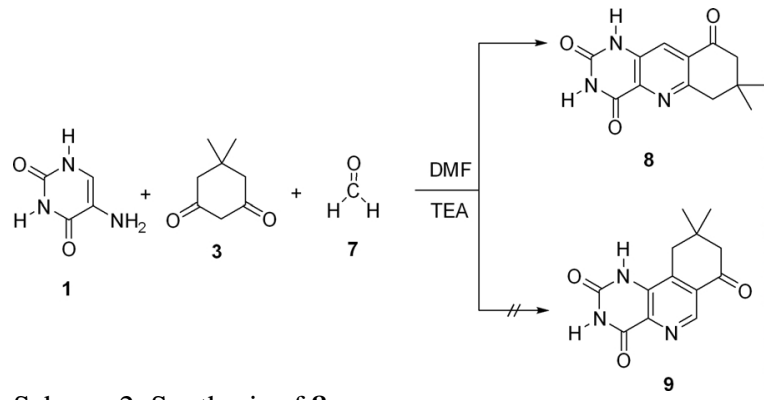

Scheme 2. Synthesis of $\mathbf{8}$.

ence of triethylamine as a catalyst gave a solid product of the composition $\mathrm{C}_{13} \mathrm{H}_{13} \mathrm{~N}_{3} \mathrm{O}_{3}(\mathrm{~m} / \mathrm{z}=259(30 \%)$, $[\mathrm{M}]^{+}$) which may be formulated as the pyrimido[5,4b] quinoline-2,4,9-trione 8 or its isomer 9 (Scheme 2). The molecular structure of $\mathbf{8}$ was indicated by its ${ }^{1} \mathrm{H}$ NMR spectrum which revealed three characteristic, relatively sharp singlets at $11.56,11.25$ and $7.93 \mathrm{ppm}$. The two former ones are assigned to the two $\mathrm{NH}$ groups, 3-NH and 1-NH, respectively, and the latter to $\mathrm{H}-10$. Two singlets appear at 3.00 and $2.62 \mathrm{ppm}$ corresponding to the two $\mathrm{CH}_{2}$ groups at positions 6 and 8, respectively, in addition to the singlet for the two methyl groups. Moreover, the ${ }^{13} \mathrm{C}$ NMR spectrum of $\mathbf{8}$ showed signals at $\delta_{C}=28.41\left(\mathrm{CMe}_{2}\right), 33.02$ (C-7), 41.88 (C-6), 50.37 (C-8), 129.01 (C-10), 133.73 (C-9a), 139.98 (C-4a), 144.62 (C-10a), 151.31 (C-6a), 162.08 (C-2), 163.31 (C-4), and 197.09 (C-9). With these spectroscopic data the proposed linear structure of $\mathbf{8}$ is identified. In the angular structure $\mathbf{9}$ the pyridine proton signal should have appeared at a higher field [29].

A proposed reaction mechanism that accounts for the multicomponent reaction is shown in Scheme 3. Thus, the reaction may occur via a condensation, addition, cyclization, and elimination mechanism. We
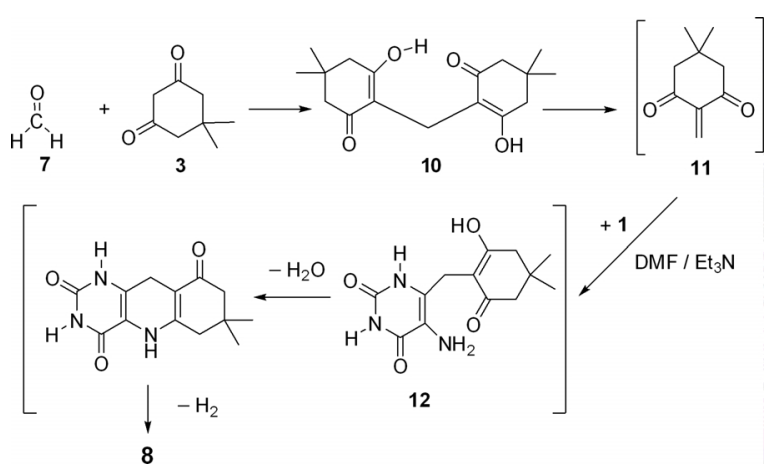

Scheme 3. Proposed mechanism to pyrimido[5,4- $b]$ quinoline-2,4,9-trione 8. assume the initial formation of the $2: 1$ dimedone/ formaldehyde adduct 10, which gives the Knoevenagel adduct intermediate 11. A subsequent Michaeltype addition reaction of the nucleophile C-6 in 5aminouracil (1) leads to the formation of intermediate 12, which undergoes cyclization with loss of a water molecule and partial oxidation to render compound 8. Neither adduct $\mathbf{1 0}$ nor $\mathbf{1 1}$ were isolated in the reaction under study. To confirm the assumed three-component condensation route we synthesized 2,2'-methylene-bis(3-hydroxy-5,5-dimethylcyclohex-2-enone) (10) [30] and brought it into reaction with compound $\mathbf{1}$ under the previous conditions. The target product formed in approximately the same yield and was identical in all aspects to compound $\mathbf{8}$ (Scheme 3).

We also studied the alkylation of $\mathbf{8}$ with ethyl iodide. The reaction was carried out at r.t. in DMF and in the presence of anhydrous potassium carbonate to afford the ethylated derivative $\mathbf{1 3}$ (Scheme 4). The structure of the product $\mathbf{1 3}$ was proved by elemental analysis and spectral data. This compound is not the $O$-ethylation product. Its IR spectrum contains bands around $1662-1708 \mathrm{~cm}^{-1}$, characteristic of carbonyl absorptions, and the ${ }^{1} \mathrm{H}$ NMR spectrum revealed that the alkylation occurs at the N-1 and N-3 atoms. Thus, the ${ }^{1} \mathrm{H}$ NMR spectrum of compound 13 contained signals from the $\mathrm{N}^{1} \mathrm{CH}_{2}(\delta=3.81)$ and $\mathrm{N}^{3} \mathrm{CH}_{2}$ protons $(\delta=3.88 \mathrm{ppm})$. Furthermore, the structure assigned to $\mathbf{1 3}$ was fully supported by its mass spectrum, which showed a molecular formula $\mathrm{C}_{17} \mathrm{H}_{21} \mathrm{~N}_{3} \mathrm{O}_{3}$ $\left(\mathrm{m} / \mathrm{z}=315(35 \%),[\mathrm{M}]^{+}\right)$. Further confirmation of structure 13 was achieved via the synthesis of the ethylated enaminoketone 15, prepared by ethylation of the enaminoketone 14 with ethyl iodide in DMF and in the

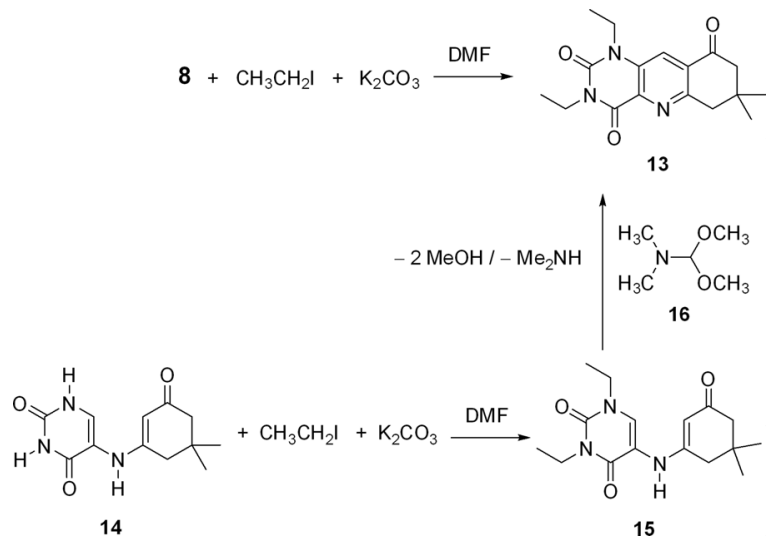

Scheme 4. Ethylation of $\mathbf{8}$ and $\mathbf{1 4 .}$ 
presence of anhydrous potassium carbonate. The IR, MS, ${ }^{1} \mathrm{H}$ NMR as well as the ${ }^{13} \mathrm{C}$ NMR spectra agreed with the proposed structure $\mathbf{1 5}$. Gentle heating of a dimethylformamide solution of $\mathbf{1 5}$ and dimethylformamide dimethyl acetal (16) at $125-135{ }^{\circ} \mathrm{C}$ for $18 \mathrm{~h}$ yielded a product identical in all aspects to compound 13 (Scheme 4).

In addition, the structure of $\mathbf{8}$ was confirmed further by an alternative synthesis of its isomer $\mathbf{9}$ (Scheme 5). Thus, reacting a mixture of 5-aminouracil (1), dimedone (3) and DMFDMA (16) in DMF without catalyst under reflux for $8 \mathrm{~h}$ afforded the pyrimidine2,4(1H,3H)-dione 18 (Scheme 5). The structure of compound $\mathbf{1 8}$ was confirmed by its elemental and spectral analyses, which showed the molecular ion peak at $m / z=277.14(98 \%)$. Its ${ }^{1} \mathrm{H}$ NMR spectrum showed characteristic singlets at $\delta=11.09$ and $11.57 \mathrm{ppm}$ for two $\mathrm{NH}$ groups, a doublet at $\delta=$ $12.29(J=15 \mathrm{~Hz})$ for an exocyclic NH group, a doublet at $\delta=8.36(J=15 \mathrm{~Hz})$ due to $\mathrm{N}-\mathrm{CH}=$, a singlet at $\delta=7.99$ due to $\mathrm{CH}$-uracil, in addition to three singlet signals for the methyl and dimedone protons. Furthermore, the structure of compound 18 was confirmed by an independent synthesis of the same compound from an equimolar amount of $\mathbf{1}$ and 2-dimethylaminomethylidenecyclohexane1,3-dione (17) in DMF under reflux to afford a product identical in all aspects to compound $\mathbf{1 8}$ (Scheme 5).

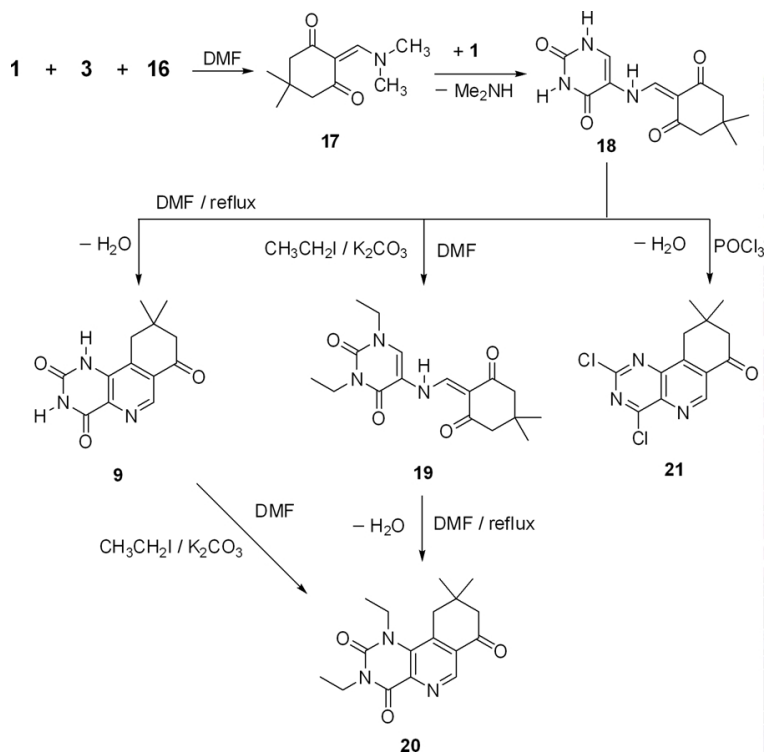

Scheme 5. Synthesis of pyrimido[5,4-c]isoquinolines $\mathbf{9 , 2 0}$ and 21.
The formation of $\mathbf{1 8}$ can be described in terms of the initial formation of the intermediate $\mathbf{1 7}$. A reaction of the latter with $\mathbf{1}$, which is accompanied by elimination of the readily leaving dimethylamino group, gives rise to $\mathbf{1 8}$ (Scheme 5). Heating a dimethylformamide solution of compound $\mathbf{1 8}$ affords the pyrimido[5,4c] isoquinoline 9 , the ${ }^{1} \mathrm{H}$ NMR spectrum of which revealed the absence of an exocyclic $\mathrm{NH}$ proton and the presence of a singlet at $\delta=8.45 \mathrm{ppm}$ due to a pyridine-CH proton. The structure of 9 was confirmed by its elemental and spectral analyses, which showed a molecular formula $\mathrm{C}_{13} \mathrm{H}_{13} \mathrm{~N}_{3} \mathrm{O}_{3}(\mathrm{~m} / \mathrm{z}=259(83.3 \%)$, $[\mathrm{M}]^{+}$). Comparison of the data of 9 with those of 8 showed differences in melting point, IR, and ${ }^{1} \mathrm{H}$ NMR data which confirmed the structure of 9 for our product.

Moreover, the ethylated derivative $\mathbf{2 0}$ was obtained by reacting 9 with ethyl iodide in DMF and in the presence of anhydrous potassium carbonate (Scheme 5). The structure of $\mathbf{2 0}$ was confirmed by its elemental and spectral analyses, which showed the molecular ion peak at $m / z=315(15 \%)$. Also, the ${ }^{1} \mathrm{H}$ NMR spectrum of 20 displayed no $\mathrm{NH}$ protons, but the presence of signals from the $\mathrm{N}^{1} \mathrm{CH}_{2}(\delta=3.86)$ and $\mathrm{N}^{3} \mathrm{CH}_{2}$ protons $(\delta=4.10 \mathrm{ppm})$. Further confirmation of structure $\mathbf{2 0}$ was obtained via the synthesis of compound $\mathbf{1 9}$, prepared by ethylation of compound $\mathbf{1 8}$. The structure of 19 was established by its correct elemental analysis and compatible spectroscopic data. Subsequent heating of $\mathbf{1 9}$ in refluxing DMF smoothly converted it to the final product $\mathbf{2 0}$ (Scheme 5). The identity of the products of the cyclization of $\mathbf{1 9}$ with those obtained by the ethylation of $\mathbf{9}$ was confirmed by comparison of their IR and ${ }^{1} \mathrm{H}$ NMR spectra.

Finally, cyclization and chlorination of compound 18 using phosphoryl chloride gave the dichloro derivative 21 (Scheme 5). The structure of the latter product was confirmed on the basis of correct elemental analysis and spectral data. Thus, the IR and ${ }^{1} \mathrm{H}$ NMR spectra of $\mathbf{2 1}$ revealed the absence of $\mathrm{NH}$ groups and signals attributable to the $\mathrm{CH}$-uracil and $\mathrm{NH}$ protons of $\mathbf{1 8}$. Also, its MS gave the characteristic fragmentation pattern due to the presence of two chlorine atoms and showed the molecular ion peak at $m / z=296(19.80 \%)$ in agreement with its molecular formula $\mathrm{C}_{13} \mathrm{H}_{11} \mathrm{Cl}_{2} \mathrm{~N}_{3} \mathrm{O}$.

In conclusion, the reported three-component onestep procedure is a simple, practical and very regioselective method for the synthesis of novel pyrimido[5,4$b$ ]quinoline-2,4,9-trione and pyrimido[5,4-c]isoquinoline derivatives. 


\section{Experimental Section}

General procedures

Melting points were measured with a Gallenkamp apparatus and are uncorrected. The reactions and purity were monitored by thin layer chromatography (TLC) on aluminum plates coated with silica gel with fluorescence indicator (Merck, $\left.60 \mathrm{~F}_{254}\right)$ using $\mathrm{CHCl}_{3}-\mathrm{CH}_{3} \mathrm{OH}(10: 1)$ as eluent. Infrared spectra were recorded in potassium bromide disks on a Jasco FT/IR-450 Plus infrared spectrophotometer. NMR spectra were obtained on a JHA-LAA 400 WB-FT spectrometer (300 MHz for ${ }^{1} \mathrm{H} \mathrm{NMR}, 75 \mathrm{MHz}$ for ${ }^{13} \mathrm{C} \mathrm{NMR}$ ), with deuterated chloroform $\left(\mathrm{CDCl}_{3}\right)$ or dimethylsulfoxide $\left(\left[\mathrm{D}_{6}\right] \mathrm{DMSO}\right)$ as solvent. Chemical shifts are quoted in $\delta$ and are referenced to TMS or the solvent signal. Mass spectra were recorded on a Trace GC 2000/Finngan Mat SSQ 7000 and a Shimadzu GCMS-QP-1000EX mass spectrometer at $70 \mathrm{eV}$. Elemental analyses were measured with a Vario EL III CHNOS Elemental Analyzer in the Microanalytical Center of Cairo University. Compounds 10 [30], 14 [17] and 17 [31] were synthesized using the published procedures.

\section{7,7-Dimethyl-7,8-dihydropyrimido[5,4-b]quinoline- 2,4,9(1H,3H,6H)-trione $(8)$}

Method A: A mixture of 5-aminouracil (1) (0.13 g, $1 \mathrm{mmol})$, dimedone (3) (0.28 g, $2 \mathrm{mmol})$ and paraformaldehyde $7(0.64 \mathrm{~g}, 2 \mathrm{mmol})$ along with triethylamine $(0.05 \mathrm{~g}$, $0.5 \mathrm{mmol}$ ) in DMF $(10 \mathrm{~mL}$ ) was refluxed for $20 \mathrm{~h}$ (TLC control using a solvent system of chloroform-methanol $(5: 2))$. The solvent was evaporated under vacuum; the resulting solid was then collected and crystallized from dioxane; yield: $81 \%$.

Method B: A solution of equimolar amounts of $2,2^{\prime}$ methylenebis (3-hydroxy-5,5-dimethylcyclohex-2-enone) (10) $(0.29 \mathrm{~g}, 1 \mathrm{mmol}), 1(0.13 \mathrm{~g}, 1 \mathrm{mmol})$ and triethylamine $(0.05 \mathrm{~g}, 0.5 \mathrm{mmol})$ in DMF $(10 \mathrm{~mL})$ was refluxed for $25 \mathrm{~h}$. Product 8 was isolated as described above; yield: $83 \%$. Brown powder, m.p. $288-290{ }^{\circ} \mathrm{C}$. - IR (film): $v=$ 3440, 2923, $1674 \mathrm{~cm}^{-1} .{ }^{1} \mathrm{H}$ NMR (300 MHz, [D 6 ]DMSO): $\delta=1.03\left(\mathrm{~s}, 6 \mathrm{H}, 2 \mathrm{CH}_{3}\right), 2.62\left(\mathrm{~s}, 2 \mathrm{H}, \mathrm{CH}_{2}\right), 3.00(\mathrm{~s}, 2 \mathrm{H}$, $\mathrm{CH}_{2}$ ), 7.93 (s, 1H, 6-H), $11.25(\mathrm{~s}, 1 \mathrm{H}, \mathrm{NH}), 11.56$ (s, $1 \mathrm{H}, \mathrm{NH}) .-{ }^{13} \mathrm{C}$ NMR $\left(75 \mathrm{MHz},\left[\mathrm{D}_{6}\right] \mathrm{DMSO}\right): \delta=28.41$, 33.02, 41.88, 50.37, 129.01, 133.73, 139.98, 144.62, 151.31, 162.08, 163.31, 197.09. - MS (EI, $70 \mathrm{eV}): \mathrm{m} / z(\%)=260$ (16.7) $[\mathrm{M}+1]^{+}, 259(30)[\mathrm{M}]^{+}$. - Anal. for $\mathrm{C}_{13} \mathrm{H}_{13} \mathrm{~N}_{3} \mathrm{O}_{3}$ (259.26): calcd. C 60.22, H 5.05, N 16.21; found C 60.39, H 5.17, N 16.34 .

\section{Ethylation of 8 and 14}

Ethyl iodide $(2.81 \mathrm{~g}, 18 \mathrm{mmol})$ was added to a mixture of 8 and/or 14 ( $3 \mathrm{mmol}$ ) and anhydrous potassium carbonate $(0.83 \mathrm{~g}, 6 \mathrm{mmol})$ in DMF $(20 \mathrm{~mL})$. The reaction mixture was stirred for $48-55 \mathrm{~h}$ at r.t. and then poured into cold water and extracted with chloroform $(3 \times 20 \mathrm{~mL})$. The combined organic extracts were washed with water and dried (anhydrous magnesium sulfate). After evaporation of some of the solvent $(\sim 10 \mathrm{~mL})$, petroleum ether $(40 \mathrm{~mL})$ was added, and the resulting precipitate was collected, dried and recrystallized from petroleum ether-chloroform and/or $n$-hexane-benzene to give $\mathbf{1 3}$ (yield $40 \%$ ), and/or $\mathbf{1 5}$ (yield $70 \%$ ), respectively.

\section{1,3-Diethyl-7,7-dimethyl-7,8-dihydropyrimido[5,4-b]quin- oline-2,4,9(1H,3H,6H)-trione (13)}

Dark-brown powder, m.p. $209-212{ }^{\circ} \mathrm{C}$. - IR (film): $v=3521,2924,2877,1708,1662.5 \mathrm{~cm}^{-1} \cdot-{ }^{1} \mathrm{H} \mathrm{NMR}$ (300 MHz, [D 6 DDSO): $\delta=0.99\left(\mathrm{~s}, 6 \mathrm{H}, 2 \mathrm{CH}_{3}\right), 1.12(\mathrm{t}$, $\left.3 \mathrm{H}, J=6 \mathrm{~Hz}, \mathrm{CH}_{3}\right), 1.23\left(\mathrm{t}, 3 \mathrm{H}, J=6 \mathrm{~Hz}, \mathrm{CH}_{3}\right), 2.32$ (s, $\left.2 \mathrm{H}, \mathrm{CH}_{2}\right), 2.40\left(\mathrm{~s}, 2 \mathrm{H}, \mathrm{CH}_{2}\right), 3.81\left(\mathrm{q}, 2 \mathrm{H}, J=6 \mathrm{~Hz}, \mathrm{CH}_{2}\right)$, $3.88\left(\mathrm{q}, 2 \mathrm{H}, J=6 \mathrm{~Hz}, \mathrm{CH}_{2}\right), 8.41(\mathrm{~s}, 1 \mathrm{H}, 10-\mathrm{H})$. - MS (EI, $70 \mathrm{eV}): m / z(\%)=316(40)[\mathrm{M}+1]^{+}, 315(35)[\mathrm{M}]^{+}$. - Anal. for $\mathrm{C}_{17} \mathrm{H}_{21} \mathrm{~N}_{3} \mathrm{O}_{3}$ (315.37): calcd. C 64.74, $\mathrm{H}$ 6.71, N 13.32; found C 64.89, H 6.59, N 13.39 .

\section{5-(5,5-Dimethyl-3-oxocyclohex-1-enylamino)-1,3-diethyl-} pyrimidine-2,4(1H,3H)-dione (15)

Yellow crystals, m.p. $238-240{ }^{\circ} \mathrm{C}$. - IR (film): $v=3205$, 3106, 2954, 2877, 1708, $1654 \mathrm{~cm}^{-1}$. - ${ }^{1} \mathrm{H}$ NMR (300 MHz, $\left.\mathrm{CDCl}_{3}\right): \delta=1.05\left(\mathrm{~s}, 6 \mathrm{H}, 2 \mathrm{CH}_{3}\right), 1.19(\mathrm{t}, 3 \mathrm{H}, J=6 \mathrm{~Hz}$, $\left.\mathrm{CH}_{3}\right), 1.28$ (t, $\left.3 \mathrm{H}, J=6 \mathrm{~Hz}, \mathrm{CH}_{3}\right), 2.18\left(\mathrm{~s}, 2 \mathrm{H}, \mathrm{CH}_{2}\right), 2.31$ (s, $2 \mathrm{H}, \mathrm{CH}_{2}$ ), 3.80 (q, 2H, J = $\left.9 \mathrm{~Hz}, \mathrm{CH}_{2}\right), 4.00$ (q, 2H, $\left.J=6 \mathrm{~Hz}, \mathrm{CH}_{2}\right), 5.41(\mathrm{~s}, 1 \mathrm{H}$, dimedone $), 6.43(\mathrm{~s}, 1 \mathrm{H}, \mathrm{CH}$ uracil), $7.24(\mathrm{~s}, 1 \mathrm{H}, \mathrm{NH}) .-{ }^{13} \mathrm{C} \mathrm{NMR}\left(75 \mathrm{MHz}, \mathrm{CDCl}_{3}\right)$ : $\delta=12.69,14.23,28.14,32.70,37.26,43.77,45.31,50.11$, $99.99,114.35,131.12,148.86,158.59,160.09,197.95 .-M S$ $(\mathrm{EI}, 70 \mathrm{eV}): \mathrm{m} / \mathrm{z}(\%)=305.15(35.58)[\mathrm{M}]^{+}, 290(100)[\mathrm{M}-$ $\left.\mathrm{CH}_{3}\right]^{+}$. - Anal. for $\mathrm{C}_{16} \mathrm{H}_{23} \mathrm{~N}_{3} \mathrm{O}_{3}$ (305.37): calcd. C 62.93, H 7.59, N 13.76; found C 62.82, H 7.71, N 13.81.

\section{An alternative synthesis of compound 13}

A solution of $\mathbf{1 5}(0.61 \mathrm{~g}, 2 \mathrm{mmol})$ and $\mathbf{1 6}(0.36 \mathrm{~g}, 3 \mathrm{mmol})$ in DMF $(5 \mathrm{~mL})$ was gently heated $\left(125-135^{\circ} \mathrm{C}\right)$ (TLC control using a solvent system of toluene-acetone (5:4)). After $18 \mathrm{~h}$, product 13 was isolated as described above; yield $50 \%$.

\section{5-((4,4-Dimethyl-2,6-dioxocyclohexylidene)methylamino)- pyrimidine-2,4(1H,3H)-dione (18)}

Method A: A solution of $\mathbf{1}(0.25 \mathrm{~g}, 2 \mathrm{mmol}), \mathbf{3}(0.28 \mathrm{~g}$, $2 \mathrm{mmol})$ and $16(0.24 \mathrm{~g}, 2 \mathrm{mmol})$ in DMF $(10 \mathrm{~mL})$ was refluxed for $8 \mathrm{~h}$ (TLC control). The solvent was evaporated under vacuum; the resulting solid was then collected and crystallized from DMF; yield: $80 \%$.

Method B: A solution of equimolar amounts of $\mathbf{1 7}(0.4$ $\mathrm{g}, 2 \mathrm{mmol})$ and $1(0.25 \mathrm{~g}, 2 \mathrm{mmol})$ in $\operatorname{DMF}(10 \mathrm{~mL})$ 
was refluxed for $8 \mathrm{~h}$. Product $\mathbf{1 8}$ was isolated as described for method A; yield $85 \%$. Pale-yellow crystals, m. p. $350-$ $352{ }^{\circ} \mathrm{C}$. - IR (film): $v=3127,3081,2954,2929,1731,1666$, $1583 \mathrm{~cm}^{-1} .-{ }^{1} \mathrm{H}$ NMR (300 MHz, [D 6 ]DMSO): $\delta=0.99$ (s, 6H, 2Me), 2.30 (s, 2H, $\mathrm{CH}_{2}$ ), 2.37 (s, 2H, $\mathrm{CH}_{2}$ ), 7.99 (s, $1 \mathrm{H}, \mathrm{CH}$ uracil), $8.36(\mathrm{~d}, 1 \mathrm{H}, J=15 \mathrm{~Hz}, \mathrm{C}=\mathrm{H}), 11.09$ (s, $1 \mathrm{H}, \mathrm{NH}$ uracil), 11.57 (s, 1H, NH uracil), 12.29 (d, 1H, $J=$ $15 \mathrm{~Hz}, \mathrm{NH}$ exocyclic). - MS (EI, $70 \mathrm{eV}): m / z(\%)=278.28$ (14) $[\mathrm{M}+1]^{+}, 277.14(98)[\mathrm{M}]^{+}$. - Anal. for $\mathrm{C}_{13} \mathrm{H}_{15} \mathrm{~N}_{3} \mathrm{O}_{4}$ (277.28): calcd. C 56.31, H 5.45, N 15.15; found C 56.22, H 5.53, N 15.11 .

\section{9,9-Dimethyl-9,10-dihydropyrimido[5,4-c]isoquinoline- 2,4,7(1H,3H,8H)-trione (9)}

A solution of compound $\mathbf{1 8}(0.28 \mathrm{~g}, 1 \mathrm{mmol})$ in DMF $(20 \mathrm{~mL})$ was refluxed for $70 \mathrm{~h}$ (TLC control). The solvent was evaporated under vacuum; the resulting solid was crystallized from dioxane, yield $45 \%$. Brown powder, m. p. $288-290{ }^{\circ} \mathrm{C}$. - IR (film): $v=3430,3340,3175,2957$, $1687 \mathrm{~cm}^{-1} .-{ }^{1} \mathrm{H}$ NMR (300 MHz, [D 6 ]DMSO): $\delta=1.12$ (s, $\left.6 \mathrm{H}, 2 \mathrm{CH}_{3}\right), 2.32\left(\mathrm{~s}, 2 \mathrm{H}, \mathrm{CH}_{2}\right), 2.40\left(\mathrm{~s}, 2 \mathrm{H}, \mathrm{CH}_{2}\right), 8.45$ (s, $1 \mathrm{H}, 6-\mathrm{H}), 11.30(\mathrm{~s}, 1 \mathrm{H}, \mathrm{NH}), 11.60(\mathrm{~s}, 1 \mathrm{H}, \mathrm{NH}) .-\mathrm{MS}(\mathrm{EI}$, $70 \mathrm{eV}): m / z(\%)=259(83.3)[\mathrm{M}]^{+} .-$Anal. for $\mathrm{C}_{13} \mathrm{H}_{13} \mathrm{~N}_{3} \mathrm{O}_{3}$ (259.26): calcd. C 60.22, H 5.05, N 16.21; found C 60.28 H 5.21, N 16.29.

\section{5-((4,4-Dimethyl-2,6-dioxocyclohexylidene)methylamino)-} 1,3-diethylpyrimidine-2,4(1H,3H)-dione (19)

Ethyl iodide $(1.87 \mathrm{~g}, 12 \mathrm{mmol})$ was added to a mixture of $18(0.56 \mathrm{~g}, 2 \mathrm{mmol})$ and anhydrous potassium carbonate $(0.83 \mathrm{~g}, 6 \mathrm{mmol})$ in DMF $(20 \mathrm{~mL})$. The reaction mixture was stirred for $36 \mathrm{~h}$ at r.t., concentrated to $3 \mathrm{~mL}$ and then poured into cold water. After stirring for $15 \mathrm{~min}$, the precipitate was collected by filtration, washed with water, dried and crystallized from petroleum ether/chloroform; yield $55 \%$. Yellow crystals, m. p. $232-234{ }^{\circ} \mathrm{C}$. - IR (film): $v=3440,2927$, 2873, 1651, $1581 \mathrm{~cm}^{-1} .-{ }^{1} \mathrm{H}$ NMR $\left(300 \mathrm{MHz}, \mathrm{CDCl}_{3}\right): \delta=$ $1.04\left(\mathrm{~s}, 6 \mathrm{H}, 2 \mathrm{CH}_{3}\right), 1.22\left(\mathrm{t}, 3 \mathrm{H}, J=6 \mathrm{~Hz}, \mathrm{CH}_{3}\right), 1.35(\mathrm{t}, 3 \mathrm{H}$, $\left.J=6 \mathrm{~Hz}, \mathrm{CH}_{3}\right), 2.36\left(\mathrm{~s}, 2 \mathrm{H}, \mathrm{CH}_{2}\right), 2.42\left(\mathrm{~s}, 2 \mathrm{H}, \mathrm{CH}_{2}\right), 3.88$ (q, $\left.2 \mathrm{H}, J=9 \mathrm{~Hz}, \mathrm{CH}_{2}\right), 4.03\left(\mathrm{q}, 2 \mathrm{H}, J=6 \mathrm{~Hz}, \mathrm{CH}_{2}\right), 7.43$ (s,
$1 \mathrm{H}$, uracil), $8.27(\mathrm{~d}, 1 \mathrm{H}, J=15 \mathrm{~Hz}), 12.45(\mathrm{~d}, 1 \mathrm{H}, J=9 \mathrm{~Hz}$, $\mathrm{NH}) .-{ }^{13} \mathrm{C} \mathrm{NMR}\left(75 \mathrm{MHz}, \mathrm{CDCl}_{3}\right): \delta=12.64,14.30,28.46$, 31.02, 37.28, 45.47, 51.30, 51.51, 115.73, 125.35, 127.97, 149.02, 158.36, 163.31, 197.40, 197.73. - MS (EI, $70 \mathrm{eV})$ : $\mathrm{m} / \mathrm{z}(\%)=335.15(8.01)[\mathrm{M}+2]^{+}, 334.15(42.27)[\mathrm{M}+1]^{+}$, 333.15 (100) $[\mathrm{M}]^{+}$. - Anal. for $\mathrm{C}_{17} \mathrm{H}_{23} \mathrm{~N}_{3} \mathrm{O}_{4}$ (333.38): calcd. C 61.25, H 6.95, N 12.60; found C 61.36, H 7.04, N 12.69 .

1,3-Diethyl-9,9-dimethyl-9,10-dihydropyrimido[5,4-c]isoquinoline-2,4,7(1H,3H,8H)-trione (20)

Method A: This compound was prepared in $42 \%$ isolated yield by ethylation of $\mathbf{9}$ using the procedure described for the synthesis of 13. The solid product was isolated and crystallized from $n$-hexane/benzene.

Method B: This compound was prepared in $50 \%$ isolated yield by heating 19 in refluxing DMF for $60 \mathrm{~h}$. The product 20 was isolated as described above. Dark-brown powder, m. p. $182-185^{\circ} \mathrm{C}$. - IR (film): $v=2931,2877,1708,1651$, $1577 \mathrm{~cm}^{-1} .-{ }^{1} \mathrm{H}$ NMR $\left(300 \mathrm{MHz}, \mathrm{CDCl}_{3}\right): \delta=1.08(\mathrm{~s}, 6 \mathrm{H}$, $2 \mathrm{Me}$ ), $1.26(\mathrm{t}, 3 \mathrm{H}, J=6 \mathrm{~Hz}, \mathrm{CHMe}), 1.35(\mathrm{t}, 3 \mathrm{H}, J=6 \mathrm{~Hz}$, $\mathrm{CHMe}) 2.65\left(\mathrm{~s}, 2 \mathrm{H}, \mathrm{CH}_{2}\right), 2.85\left(\mathrm{~s}, 2 \mathrm{H}, \mathrm{CH}_{2}\right), 3.86(\mathrm{q}, 2 \mathrm{H}$, $\left.J=9 \mathrm{~Hz}, \mathrm{CH}_{2}\right), 4.10\left(\mathrm{q}, 2 \mathrm{H}, J=6 \mathrm{~Hz}, \mathrm{CH}_{2}\right), 8.27(\mathrm{~s}, 1 \mathrm{H}$, $\mathrm{CH})$. - MS (EI, $70 \mathrm{eV}): \mathrm{m} / \mathrm{z}(\%)=315(15)[\mathrm{M}]^{+}, 314(10)$ $[\mathrm{M}-1]^{+}$. - Anal. for $\mathrm{C}_{17} \mathrm{H}_{21} \mathrm{~N}_{3} \mathrm{O}_{3}$ (315.37): calcd. C 64.74, $\mathrm{H}, 6.71, \mathrm{~N} 13.32$; found $\mathrm{C} 64.79, \mathrm{H}, 6.82, \mathrm{~N} 13.38$.

\section{2,4-Dichloro-9,9-dimethyl-9,10-dihydropyrimido[5,4-c]iso- quinoline-7(8H)-one (21)}

Compound 18 ( $0.56 \mathrm{~g}, 2 \mathrm{mmol})$ was refluxed in phosphorus oxychloride $(5 \mathrm{~mL})$ for $12 \mathrm{~h}$. The mixture was cooled and poured onto ice-water to give a precipitate which was filtered off, dried and recrystallized from petroleum ether/methylene chloride to afford 21. Yield 50\%. Brown powder, m. p. $222-$ $224{ }^{\circ} \mathrm{C}$. - IR (film): $v=2958,2831,1697,1512 \mathrm{~cm}^{-1}$. ${ }^{1} \mathrm{H}$ NMR (300 MHz, [D 6 ]DMSO): $\delta=1.07$ (s, 6H, 2Me), 2.72 (s, $\left.2 \mathrm{H}, \mathrm{CH}_{2}\right), 2.86\left(\mathrm{~s}, 2 \mathrm{H}, \mathrm{CH}_{2}\right), 8.32(\mathrm{~s}, 1 \mathrm{H}, \mathrm{CH})$. MS (EI, $70 \mathrm{eV}): m / z(\%)=297(21.05)[\mathrm{M}+1]^{+}, 296(19.75)$ $[\mathrm{M}]^{+}, 295.00(13.25)[\mathrm{M}-1]^{+}$. - Anal. for $\mathrm{C}_{13} \mathrm{H}_{11} \mathrm{Cl}_{2} \mathrm{~N}_{3} \mathrm{O}$ (296.15): calcd. C 52.72, H 3.74, N 14.19; found C 52.81, H 3.81, N 14.25.
[1] A. Dömling, Chem. Rev. 2006, 106, 17.

[2] A. A. Joshi, C.L. Viswanathan, Agent. Med. Chem. 2006, 5, 105.

[3] A. A. Joshi, S. S. Narkhede, C. L. Viswanathan, Bioorg. Med. Chem. Lett. 2005, 15, 73.

[4] L. Cordeu, E. Cubedo, E. Bandres, A. Rebollo, X. Saenz, H. M. Chozes, V. Dominquez, M. Echeverria, B. Mendivil, C. Sanmartin, J. A. Palop, M. Font, J. Garcia-Foncillas, Bioorg. Med. Chem. 2007, 15, 1659.
[5] S. I. Alqasoumi, A. M. Al-Taweel, A. M. Alafeefy, E. Noaman, M. M. Ghorab, Eur. J. Med. Chem. 2010, 45,738 .

[6] S. T. Selvi, V. Nadaraj, S. Mohan, R. Sasi, M. Hema, Bioorg. Med. Chem. 2006, 14, 3896.

[7] H. I. Ali, N. Ashida, T. Nagamatsu, Bioorg. Med. Chem. 2007, 15, 6336.

[8] A. B. A. El-Gazzar, H.N. Hafez, G. A.M. Nawwar, Eur. J. Med. Chem. 2009, 44, 1427. 
[9] O. A. El-Sayed, T. M. Al-Turki, H. M. Al-Daffiri, B. A. Al-Bassam, M.E. Hussein, Boll. Chim. Farm. 2004, 143, 227.

[10] C. J. Li, Chem. Rev. 2005, 105, 3095.

[11] J. Quiroga, J. Portilla, H. Serrano, R. Abonía, B. Insuasty, M. Nogueras, J. Cobo, Tetrahedron Lett. 2007, 48, 1987.

[12] C. Simon, T. Constantieux, J. Rodriguez, Eur. J. Org. Chem. 2004, 24, 4957.

[13] S. L. Cui, X. F. Lin, Y. G. Wang, J. Org. Chem. 2005, $70,2866$.

[14] Y. J. Huang, F. Y. Yang, C. J. Zhu, J. Am. Chem. Soc. 2005, 127, 16386.

[15] D. J. Ramón, M. Yus, Angew. Chem. 2005, 117, 1628; Angew. Chem. Int. Ed. 2005, 44, 1602.

[16] G. Shanthi, G. Subbulakshmi, P. T. Perumal, Tetrahedron 2007, 63, 2057.

[17] R. M. Shaker, M. Abd Elrady, Z. Naturforsch. 2008, $63 b, 1431$.

[18] R. M. Shaker, M. A. Ameen, A. M. Abdel Hameed, M. Abd Elrady, Z. Naturforsch. 2009, 64b, 1193.
[19] K. M. El-Shaieb, R. M. Shaker, A. A. Aly, Synth. Commun. 2008, 38, 2054.

[20] R. M. Shaker, Arkivoc 2006, xiv, 59.

[21] R. M. Shaker, Arkivoc 2006, xiv, 68.

[22] A. A. Aly, A. A. Hassan, K. M. El-Shaieb, R. M. Shaker, Z. Naturforsch. 2005, 60b, 999.

[23] R. M. Shaker, Heteroatom Chem. 2005, 16, 507.

[24] A. A. Hassan, K. M. El-Shaieb, R. M. Shaker, D. Döpp, Heteroatom Chem. 2005, 16, 12.

[25] R. A. Mekheimer, A. Abdel Hameed, K. U. Sadek, Green Chem. 2005, 10, 592.

[26] M. A. Barsy, F. M. Abdel Latif, A. A. Arey, K. U. Sadek, Green Chem. 2002, 4, 196.

[27] F. Al-Qalaf, R. A. Mekheimer, K. U. Sadek, Molecules 2008, $B, 2908$.

[28] R. A. Mekheimer, A. Abdel Hameed, S. A. A. Mansour, K. U. Sadek, Chinese Chem. Lett. 2009, 20, 812

[29] H. Junek, I. Wrtilek, Monatsh. Chem. 1970, 101, 1130.

[30] K. Nagarajan, S. J. Shenoy, Ind. J. Chem. 1992, 31, 73.

[31] P. Schenone, L. Mosti, G. Menozzi, J. Heterocyclic Chem. 1982, 19, 1355. 